\title{
Pengaruh Metode Pembelajaran dan Kemampuan Berpikir Kritis Terhadap Kesadaran Sejarah Siswa SMA Islam Al Azhar Kelapa Gading Jakarta
}

\author{
Wage Wardana, Tuti Nuriah, Asmaniar \\ Pendidikan Sejarah, Pascasarjana Universitas Negeri Jakarta \\ wage unj@yahoo.co.id
}

\begin{abstract}
The aim of study is to reveal the effect of learning methods and critical thinking style to student historical consciousness in Al Azhar Kelapa Gading Senior High School Jakarta. This research used is the experimental method. Research instrumentation will include a test that will be used to measure students history awareness from instructional methods and critical thinking style of students. As for out come of this research are : (1) Student's historical consciousness who are using the problem solving method will higher than students who used conventional method, (2)There is an interaction between learning method and critical thinking style toward historical consciousness, (3) Student's historical consciousness who have a high critical thinking and use a problem solving method are higher than students who have a high critical thinking style using a conventional method, (4) Student's historical consciousness who have a low critical thinking style and using a problem solving methods are lower than students who have a high critical thinking style using a conventional methods.
\end{abstract}

Keywords : historical awareness, instructional methods, critical thinking style

\begin{abstract}
Abstrak: Penelitian ini bertujuan untuk mengetahui pengaruh metode pembelajaran dan kemampuan berpikir kritis terhadap kesadaran sejarah siswa di SMA Islam Al Azhar Kelapa Gading Jakarta. Metode yang digunakan adalah metode eksperimen. Instrumen penelitian bertujuan mengukur kesadaran sejarah siswa dari metode pembelajaran yang diuji-cobakan dan kemampuan berpikir kritis siswa. Hasil penelitian adalah sebagai berikut: (1) Tingkat kesadaran sejarah sejarah siswa yang menggunakan pembelajaran dengan metode problem solving lebih tinggi dari siswa yang menggunakan metode pembelajaran konvensional. (2) Terdapat pengaruh interaksi antara metode pembelajaran dan kemampuan berpikir kritis terhadap kesadaran sejarah siswa. (3) Tingkat kesadaran sejarah siswa yang berpikir kritis tinggi dan menggunakan metode pembelajaran pemecahan masalah lebih tinggi dari siswa yang berpikir kritis tinggi dan menggunakan metode pembelajaran konvensional. (4) Kesadaran sejarah siswa yang berpikir kritis rendah dan menggunakan metode pemecahan masalah lebih rendah dari siswa yang memiliki kemampuan berpikir kritis rendah dan menggunakan metode pembelajaran konvensional.
\end{abstract}

Kata Kunci : kesadaran sejarah siswa, metode pembelajaran, kemampuan berpikir kritis

\section{PENDAHULUAN}

Kegiatan peneliti sebelum melakukan penelitian adalah melakukan observasi awal di SMA Islam Al Azhar Kelapa Gading Jakarta. Hasil observasi menemukan berbagai masalah. Masalah yang sangat menonjol yaitu metode pembelajaran guru dan opini siswa terhadap guru dan pelajaran sejarah. Siswa menyatakan bahwa kegiatan pembelajaran sejarah umumnya didominasi oleh mendengar, mencatat, menghapal dan 
berorientasi ke masa lalu. Keadaan seperti itu membuat mereka cenderung menunggu informasi dari guru daripada aktif mencari informasi.

Masalah lain menyatakan bahwa guru sering menggunakan metode pembelajaran konvensional dan menjelaskan materi pembelajaran dengan Power Point. Metode ceramah selalu menjadi pilihan guru sejarah dalam menyampaikan materi pelajaran kepada siswa. Keadaan seperti itu membuat situasi kelas cenderung monotone dan membosankan.

Proses pembelajaran seharusnya menggambarkan keadaan yang aktif, dinamis dan menyenangkan. Keadaan aktif akan tercapai kalau guru dan siswa berinteraksi aktif, sehingga kelas menjadi dinamis dan komunikatif. Keadaan diatas akan membuat siswa tidak hanya berorientasi kepada masa lalu, tetapi juga masa kini dan mendatang.

Metode pembelajaran memegang peranan penting dalam mengatasi permasalahan tersebut. Oleh karena itu, guru perlu memiliki kemampuan dalam memilih metode pembelajaran yang tepat. Metode pembelajaran yang tepat diharapkan dapat memberikan suasana yang berbeda dalam pembelajaran dan guru juga bisa leluasa menanamkan tujuan dari pembelajaran.

Hasil penelitian yang relevan dengan penelitian ini dilakukan Aman dengan judul "Aktualisasi Nilai-Nilai Kesadaran Sejarah dan Nasionalisme dalam Pembelajaran Sejarah Siswa di SMA). Peneliti adalah mahasiswa Fakultas Ilmu Sosial Universitas Negeri Yogyakarta. Aman (2011: 140) menyatakan bahwa aktualisasi nilai-nilai kesadaran sejarah dapat ditunjukkan melalui penananam penghayatan arti penting sejarah untuk masa kini dan mendatang, mengenal diri sendiri dan bangsanya, pembudayaan sejarah bagi pembinaan budaya bangsa; dan menjaga peninggalan sejarah bangsa.

Berdasarkan latar belakang masalah tersebut peneliti tertarik melakukan penelitian mengenai " Pengaruh Metode Pembelajaran dan Kemampuan Berpikir Kritis Terhadap Kesadaran Sejarah di SMA Islam Al Azhar Kelapa Gading, Jakarta" .

Penelitian ini akan memaparkan metode pembelajaran pemecahan masalah dan metode pembelajaran konvensional. Dewey dalam Thobroni (2015; 276) menyatakan bahwa metode pembelajaran pemecahan masalah adalah sebuah metode pembelajaran yang mempunyai enam tahapan yang saling terkait yaitu, merumuskan masalah, menelaah masalah, mengumpulkan data sebagai bahan pembuktian hipotesis, pembuktian hipotesis, hingga menentukan penyelesaian. Kalau kita lihat dari tahapan yang disampaikan oleh Dewey tersebut, maka siswa dituntut bakal mandiri dalam memecahkan masalah dan mencari solusi. atas segala permasalahan yang di dapatnya dalam kehidupan sehari-hari. 
Pemilihan metode pemecahan masalah diharapkan dapat menjadi alternative bagi metode pembelajaran yang efektif ditengah dominannya metode pembelajaran konvensional yang marak dilakukan guru. Metode pemecahan masalah menuntut siswa jadi student center dalam pembelajaran di kelas. Menurut Arends (2010;297) metode pembelajaran konvensional berorientasi pada guru dan memiliki lima tahapan, yaitu mempersiapkan materi, menjelaskan / mendemonstrasikan materi, memandu praktek, memberikan umpan balik dan memberikan tindak lanjut materi. Sehingga guru dominan dan siswa hanya menunggu informasi dari guru. Keadaan inilah yang membuat peneliti kemudian menerapkan penelitian metode pemecahan masalah.

Ennis dalam Hasruddin (2009:50) menyatakan bahwa berpikir kritis adalah berpikir secara beralasan dan reflektif dengan menekankan pembuatan keputusan tentang apa yang harus dipercayai atau atau dilakukan. Penekanan Ennis mengenai kemampuan berpikir kritis menekankan kepada dua hal penting yaitu pembuatan keputusan dan apa yang harus dilakukan. Dua hal tersebut sangat penting dalam kehidupan, sehingga kemampuan berpikir kritis menjadi sangat penting. Hal tersebut relevan dengan apa yang diungkapkan oleh Harris dalam Hassan (2012: 130) yang menyatakan bahwa berpikir kritis adalah "a habit of cautious evaluation, an analytic mindset aimed at discovering component parts of ideas and philosophies, eager to weigh the merits of arguments and reasons in order to become a good judge of them". Definisi tersebut menyatakan bahwa berpikir kritis itu adalah sebuah kebiasaan, dimana kebiasaan itu bisa dikembangkan lewat pendidikan yang berjenjang, sistematis dan berkelanjutan. Proses pendidikan tersebut selain memerlukan kesinambungan dan berjenjang juga memerlukan penguatan, sehingga akhirnya kebiasaan itu menjadi bagian dari jati diri seseorang. Kemampuan berpikir kritis adalah landasan utama menjadi manusia cerdas, orang yang mempunyai kemampuan berpikir kritis rasa ingin tahunya sangat besar, sehingga ia akan terus mencari jawaban atas persoalan-persoalan yang dihadapinya.

Eggen dan Kauchak (2010: 271) menyatakan bahwa bahwa berpikir kritis merupakan "an individual's ability and inclination to make and asses conclusions based on evidence". Berpikir kritis menurut Eggen dan Kauchak adalah kemampuan dan kecenderungan individu untuk membuat dan menilai kesimpulan berdasarkan bukti yang ada. Perpaduan antara metode pembelajaran pemecahan masalah dan kemampuan berpikir kritis diharapkan akan menimbulkan kesadaran sejarah bagi siswa. Reichenbach (2001:13) menegaskan bahwa kemampuan berpikir kritis dimulai dengan pengetahuan dan pemahaman seseorang terhadap sebuah peristiwa. 
Jeismann dalam Thorp (2014; 21) menyatakan bahwa "Historical consciousness as anotion that '[incorporates] the connection between interpretation of the past, understanding of the present, and perspective on the future". Artinya memang terdapat hubungan antara interpretasi masa lalu, pemahaman masa kini dan perspektif tentang masa depan. Wineburg dalam Putro (2012: 208) menyatakan bahwa guru memberikan pembelajaran dengan format menghapal dan siswa kurang diajak untuk melakukan interpretasi.

Tujuan operasional penelitian ini adalah untuk mengetahui beberapa hal mengenai : 1) Perbedaan kesadaran sejarah siswa yang menggunakan metode pemecahan masalah dan siswa yang menggunakan metode pembelajaran konvensional. 2) Pengaruh interaksi metode pembelajaran dan kemampuan berpikir kritis terhadap kesadaran sejarah yang dicapai siswa. 3) Perbedaan kesadaran sejarah antara siswa yang memiliki kemampuan berpikir kritis tinggi dan menggunakan metode pembelajaran pemecahan masalah dengan siswa yang memiliki kemampuan berpikir kritis tinggi dan menggunakan metode pembelajaran konvensional. 4) Perbedaan kesadaran sejarah antara siswa yang memiliki kemampuan berpikir kritis rendah dan menggunakan metode pembelajaran pemecahan masalah dengan siswa yang memiliki kemampuan berpikir kritis rendah dan menggunakan metode pembelajaran konvensional

\section{METODE}

Metode yang digunakan dalam penelitian ini adalah eksperimen dengan Design Treatmen by level 2 x 2. Penelitian ini merupakan penelitian eksperimen menggunakan satu kelas kontrol dengan metode pembelajaran konvensional dan satu kelas eksperimen dengan metode pembelajaran pemecahan masalah.

Populasi target dalam penelitian ini adalah seluruh siswa SMA Islam Al-Azhar Kelapa Gading, sedangkan populasi terjangkaunya adalah kelas XI IPS 2 dan kelas XI IPS 3 yang berjumlah 56 orang. Kelas XI IPS 2 terdiri dari 29 siswa dan kelas XI IPS 3 berjumlah 27 siswa.

Langkah awal yang peneliti lakukan adalah menentukan secara acak kelas yang akan dijadikan sebagai tempat pelaksanaan pembelajaran dengan metode pemecahan masalah dan tempat pelaksanaan pembelajaran dengan metode konvensional. Melalui penetapan secara acak diperoleh kelas XI IPS 3 sebagai kelas yang melaksanakan metode pemecahan masalah dan XI IPS 2 sebagai kelas yang melaksanakan metode konvensional sebelum diberi perlakuan, siswa yang berada dalam dua kelas ini diberikan kuesioner untuk mendapatkan data skor kecenderungan berpikir kritis. Hasilnya kemudian diurutkan masing-masing dari skor tertinggi ke skor terendah. 
Naga menyatakan (1992: 54) bahwa penetapan kelompok tinggi dan rendah dalam penelitian ini menggunakan pembagian $28 \%$ kelompok tinggi dan $28 \%$ kelompok rendah sebagai sampel. Penetapan dilakukan untuk pengukuran dan pengelompokkan siswa berdasarkan kecenderungan berpikir kritis tinggi dan rendah. Berdasarkan skor hasil pengujian instrument kecenderungan berpikir kritis pada kelas kontrol dan eksperimen yang telah diurutkan dari skor tertinggi sampai skor terendah menggunakan rumus $\mathrm{M}_{\mathrm{T}}=\mathrm{M}_{\mathrm{R}}$, untuk kelas eksperimen sampel yang ditetapkan untuk bagian atas dan bawah ditetapkan $28 \%$ dari 29 siswa, sehingga diperoleh jumlah 8 siswa dari kelompok yang memiliki kecenderungan berpikir kritis tinggi dan 8 siswa dari kelompok yang memiliki kecenderungan berpikir kritis rendah. Penetapan yang sama untuk kelas kontrol dengan menggunakan pembagian $28 \%$ kelompok tinggi dan $28 \%$ kelompok rendah dari 27 siswa. Pada kelas kontrol ditetapkan $28 \%$ pada bagian atas dan bawah dari 27 siswa sehingga diperoleh jumlah 8 siswa dari kelompok yang memiliki kecenderungan berpikir kritis tinggi dan 8 siswa dari kelompok yang memiliki kecenderungan berpikir kritis rendah. Intinya dapat disimpulkan terdapat 32 siswa yang ditetapkan sebagai sampel. Komposisi anggota sampel penelitian berjumlah 32, 16 dari kelas eksperimen dan 16 dari kelas kontrol, dideskripsikan dalam tabel 3.2 berikut:

Data yang dikumpulkan melalui penelitian ini meliputi data kesadaran sejarah siswa dan kemampuan berpikir kritis siswa pada mata pelajaran sejarah. Instrument yang digunakan untuk mengukur kemampuan berpikir kritis berbentuk tes pilihan sikap. Tes tersebut untuk mengukur kesadaran sejarah siswa sesuai dengan empat aspek yang diukur. Adapun jumlah pilihan ada lima yaitu sangat setuju, setuju, kurang setuju, tidak setuju dan sangat tidak setuju, Untuk menguji validitas butir soal dan menghitung koefisien korelasi antara skor butir soal dengan skor total instrument digunakan perhitungan dengan menggunakan rumus koefisien korelasi Product Moment ( r ) dari Pearson, Arikunto (2014: 314) menyatakan bahwa $r$ digunakan untuk menguji dua gejala interval. Pengujian reliabilitas akan dihitung dengan menggunakan rumus koefisien alpha atau Alpha Cronbach.

Jenis instrument kemampuan berpikir kritis berupa tes pilihan sikap Untuk menguji validitas butir soal (validitas internal) dan menghitung koefisisen korelasi antara skor butir soal dengan skor total instrumen digunakan penghitungan dengan menggunakan rumus koefisien korelasi Product Moment (r) dari Pearson. Kriteria pengambilan keputusan bahwa butir soal adalah valid ditentukan dengan jika $r$ hitung $>r$ tabel, jika hasil penghitungan menunjukkan keterangan yang sebaliknya, maka butir soal tidak valid, dan tidak bisa digunakan untuk menjaring data penelitian. 
Pengujian reliabilitas akan dihitung dengan menggunakan rumus koefisien alpha atau Alpha Cronbach.

Data yang diperoleh melalui instrumen penelitian dianalisis menggunakan analisis deskriptif dan inferensial. Analisis deskriptif dilakukan dengan penyajian table distribusi, histogram, rata-rata, dan simpangan baku. Uji normalitas dalam penelitian ini menggunakan uji Liliefors, sedangkan uji homogenitas menggunakan uji Bartlett pada taraf $\alpha=$ 0.05. uji hipotesis dalam penelitian ini menggunakan uji analisis variansi (ANAVA) untuk menguji efek utama dan pengaruh interaksi antar A dan B. pengujian dilanjutkan dengan menggunakan uji Tuckey untuk melihat hasil perbandingan diantara kelompok perlakuan penelitian.

\section{HASIL}

Pengujian hipotesis dilakukan untuk menguji semua efek utama dan efek interaksi terhadap kesadaran sejarah dengan menggunakan analisis varians dua jalur (ANAVA) desain treatment by level $2 \times 2$. Efek utama data penelitian ini adalah pengaruh metode pembelajaran terhadap kesadaran sejarah siswa SMA Islam Al-Azhar Kelapa Gading, Jakarta. Efek interaksi yaitu pengaruh interaksi antara metode pembelajaran dengan kemampuan berpikir kritis tinggi dan rendah. Taraf signifikansinya dilakukan dengan uji lanjut menggunakan uji Tuckey.

Tabel 1

Rangkuman Hasil Perhitungan Analisis Varians (ANAVA) Dua Jalur

\begin{tabular}{|l|c|c|r|r|r|}
\hline \multicolumn{1}{|c|}{ Sumber Varians } & Db & JK & RK =JK/db & Fh =RKIRKD & Ft 0,05 \\
\hline Metode Pembelajaran (A) & 1 & 81,28 & 81,28 & $18,946^{* *}$ & 4,20 \\
\hline Berpikir Kritis (B) & 1 & 38,28 & 38,28 & $8,923^{* *}$ & 4,20 \\
\hline Interaksi (A x B) & 1 & 318,78 & 318,78 & $74,305^{* *}$ & 4,20 \\
\hline Kekeliruan (D) & 28 & 120,13 & 4,29 & & \\
\hline Total Dikoreksi (TR) & 31 & 558,47 & & & \\
\hline
\end{tabular}

Terdapat perbedaan tingkat kesadaran sejarah yang antara siswa yang mendapat pembelajaran dengan menggunakan metode pembelajaran pemecahan masalah dan metode konvensional.

Hipotesis ini secara statistik dirumuskan sebagai berikut:

$\mathrm{H}_{0}: \mu \mathrm{A} 1 \leq \mu \mathrm{A} 2$

$\mathrm{H}_{1}: \mu \mathrm{A} 1>\mu \mathrm{A} 2$

Keterangan : 
$\mu \mathrm{A}_{1}$ : rata-rata skor kesadaran sejarah yang menggunakan metode pembelajaran pemecahan masalah.

$\mu \mathrm{A}_{2}$ : rata-rata skor kesadaran sejarah yang menggunakan metode pembelajaran konvensional.

Berdasarkan perhitungan ANAVA dua jalur diperoleh Fhitung untuk metode pembelajaran 18,946, sedangkan Ftabel $=4,20$ pada taraf $\mathrm{a}=0,05$. Karena nilai $F_{\text {hitung }}>\mathrm{F}_{\text {tabel, }}$ maka $\mathrm{H}_{0}$ ditolak dan $\mathrm{H}_{1}$ diterima. Artinya kesadaran sejarah siswa yang menggunakan metode pembelajaran pemecahan masalah lebih tinggi dari siswa yang menggunakan metode pembelajaran konvensional.

Terdapat pengaruh interaksi antara penggunaan metode pembelajaran dan Kemampuan Berpikir Kritis terhadap Tingkat Kesadaran sejarah siswa SMA. Hipotesis ini secara statistik dirumuskan sebagai berikut

Ho: Int. $\mathrm{A} \times \mathrm{B}=0$

$\mathrm{H}_{1}$ : Int. $\mathrm{A} \times \mathrm{B} \neq 0$

Keterangan :

Ho: Tidak terdapat pengaruh interaksi antara penggunaan metode pembelajaran dan berpikir kritis terhadap kesadaran sejarah siswa SMA.

$\mathrm{H}_{1}$ : Terdapat pengaruh interaksi antara penggunaan metode pembelajaran dan berpikir kritis siswa terhadap kesadaran sejarah siswa SMA.

Berdasarkan hasil perhitungan ANAVA dapat dilihat bahwa Fhitung untuk faktor interaksi yaitu 74,305 lebih besar daripada Ftabel yaitu 4,20 pada taraf nyata $\alpha=0,05$. Hal ini menunjukkan terdapat pengaruh interaksi antara penggunaan metode pembelajaran dan berpikir kritis siswa terhadap kesadaran sejarah siswa SMA. Dengan demikian maka $\mathrm{H}_{0}$ ditolak dan $\mathrm{H}_{1}$ diterima.

Hipotesis statistik dirumuskan sebagai berikut:

$\mathrm{H}_{0}: \mu \mathrm{A}_{1} \mathrm{~B}_{1} \leq \mu \mathrm{A}_{2} \mathrm{~B}_{1}$

$\mathrm{H}_{1}: \mu \mathrm{A}_{1} \mathrm{~B}_{1}>\mu \mathrm{A}_{2} \mathrm{~B}_{1}$

Keterangan:

$\mu \mathrm{A}_{1} \mathrm{~B}_{1}$ : rata-rata nilai kesadaran sejarah siswa yang memiliki kemampuan kemampuan berpikir kritis tinggi menggunakan metode pembelajaran pemecahan masalah.

$\mu \mathrm{A}_{2} \mathrm{~B}_{1}$ : rata-rata nilai kesadaran sejarah siswa yang memiliki kemampuan kemampuan berpikir kritis tinggi menggunakan metode pembelajaran konvensional.

Nilai rerata kesadaran sejarah siswa SMA yang memiliki kemampuan berpikir kritis tinggi bila diberikan metode pembelajaran Pemecahan Masalah $\left(\mathrm{A}_{1} \mathrm{~B}_{\mathrm{I}}\right)$ adalah 33,13. Sedangkan nilai rerata kesadaran sejarah siswa 
SMA yang memiliki kemampuan berpikir kritis tinggi bila diberikan metode pembelajaran konvensional $\left(A_{2} B_{1}\right)$ adalah 23,63. Kedua nilai rerata ini dibandingkan dengan menggunakan Uji Tuckey yang dilambangkan dengan Q12 sebagai berikut.

$$
Q_{4}=\frac{(33,13-23,63)}{\sqrt{\frac{4,29}{8}}}=12,97
$$

Hasil ini menunjukkan bahwa Qhitung yaitu 12,97 > Qtabel yaitu 4,04 pada taraf nyata $\alpha=0,05$. Dengan demikian maka dapat disimpulkan bahwa Ho ditolak dan $\mathrm{H}_{1}$ diterima yang berarti bahwa kesadaran sejarah siswa yang memiliki kemampuan berpikir kritis tinggi dan menggunakan metode pemecahan masalah lebih tinggi dari siswa yang memiliki kemampuan berpikir kritis tinggi dan menggunakan metode pembelajaran konvensional. Rangkuman hasil Uji Tuckey dapat dilihat pada tabel di bawah ini.

Untuk siswa yang memiliki kemampuan kemampuan berpikir kritis rendah, terdapat perbedaan tingkat kesadaran sejarah siswa jika diberikan pembelajaran dengan metode pemecahan masalah dan konvensional. Hipotesis ini secara statistik dirumuskan sebagai berikut:

$\mathrm{H}_{0}: \mu \mathrm{A}_{1} \mathrm{~B}_{2} \geq \mu \mathrm{A}_{2} \mathrm{~B}_{2}$

$\mathrm{H}_{1}: \mu \mathrm{A}_{1} \mathrm{~B}_{2}<\mu \mathrm{A}_{2} \mathrm{~B}_{2}$

$\mu \mathrm{A}_{1} \mathrm{~B}_{2}$ : Rerata nilai Kesadaran sejarah siswa SMA yang memiliki kemampuan kemampuan berpikir kritis rendah bila diberikan metode pembelajaran pemecahan masalah.

$\mu \mathrm{A}_{2} \mathrm{~B}_{2}$ : Rerata nilai kesadaran sejarah siswa SMA yang memiliki kemampuan berpikir kritis rendah bila diberikan metode pembelajaran konvensional.

Nilai rerata kesadaran sejarah siswa SMA yang memiliki kemampuan kemampuan berpikir kritis rendah bila diberikan metode pembelajaran pemecahan masalah $\left(\mathrm{A}_{1} \mathrm{~B}_{2}\right)$ adalah 24,63. Sedangkan nilai rerata kesadaran sejarah sejarah siswa SMA yang memiliki kemampuan berpikir kritis rendah bila diberikan metode pembelajaran konvensional $\left(A_{2} \mathrm{~B}_{2}\right)$ adalah 27,75. Kedua nilai rerata ini dibandingkan dengan menggunakan Uji Tuckey dan diperoleh nilai $\mathrm{Q}_{34}$ seperti berikut:

$$
Q_{5}=\frac{(24,63-27,75)}{\sqrt{\frac{4,29}{8}}}=4,27
$$

Hasil ini menunjukkan bahwa nilai $Q_{\text {hitung }}=4,27>$ nilai $Q_{\text {tabel }}=4,04$ untuk taraf nyata $\alpha=0,05$. Dengan demikian maka dapat disimpulkan bahwa Ho ditolak dan $\mathrm{H}_{1}$ diterima, hal tersebut berarti bahwa kesadaran sejarah siswa yang memiliki kemampuan berpikir kritis rendah dan menggunakan metode pemecahan masalah lebih rendah dari siswa yang 
memiliki kemampuan berpikir kritis rendah dan menggunakan metode pembelajaran konvensional. Hal ini menunjukkan bahwa siswa yang memiliki kemampuan berpikir kritis rendah lebih cocok diberikan pembelajaran dengan menggunakan metode pembelajaran konvensional.

\section{PEMBAHASAN}

Hasil analisi varians (ANAVA) dua jalur, menyatakan bahwa hipotesis nol yang menyatakan tidak ada perbedaan yang signifikan kesadaran sejarah antara siswa yang mendapat pembelajaran dengan menggunakan metode pembelajaran pemecahan masalah dan metode konvensional ditolak. Hal ini berarti bahwa secara keseluruhan terdapat pengaruh dari metode pembelajaran (pemecahan masalah dan konvensional) terhadap kesadaran sejarah sejarah siswa.

Jika dianalisis lebih jauh dengan menggunakan Uji Tuckey ternyata penggunaan metode pembelajaran pemecahan masalah memiliki efek yang lebih tinggi bagi peningkatan kesadaran sejarah siswa SMA. Siswa memperoleh kesadaran sejarah yang lebih baik jika diberikan metode pembelajaran pemecahan masalah

Hasil Analisis Varians dua jalur, menyatakan bahwa $\mathrm{F}$ hitung $=74,305$ lebih besar daripada $F_{\text {tabel }}$ yaitu 4,20. Hal tersebut menunjukkan bahwa hipotesis nol yang menyatakan tidak ada pengaruh interaksi antara penggunaan metode pembelajaran dan kemampuan berpikir kritis terhadap kesadaran sejarah siswa yang mendapat pembelajaran dengan menggunakan metode pembelajaran pemecahan masalah dan metode konvensional ditolak dan $\mathrm{H}_{1}$ yang menyatakan terdapat pengaruh interaksi antara penggunaan metode pembelajaran dan kemampuan berpikir kritis terhadap kesadaran sejarah siswa yang mendapat pembelajaran dengan menggunakan metode pembelajaran pemecahan masalah dan metode konvensional diterima

Hasil uji hipotesis ketiga menerima hipotesis yang menyatakan bahwa untuk siswa yang mempunyai kemampuan berpikir kritis tinggi, terdapat perbedaan kesadaran sejarah siswa jika diberikan pembelajaran dengan metode konvensional dan pemecahan masalah. Hal ini menunjukkan bahwa siswa yang kemampuan berpikir kritis tinggi, lebih cocok jika belajar dengan menggunakan metode pemecahan masalah daripada menggunakan metode konvensional.

Jika dianalisis lebih jauh dengan menggunakan uji Tuckey, maka dapat dilihat bahwa penggunaan metode pemecahan masalah untuk siswa yang memiliki kemampuan kemampuan berpikir kritis tinggi memiliki efek yang lebih tinggi terhadap kesadaran sejarah siswa.

Hipotesis keempat yang menyatakan bahwa terdapat perbedaan 
kesadaran sejarah bagi siswa yang memiliki kemampuan berpikir kritis rendah jika diberikan pembelajaran dengan menggunakan metode pemecahan masalah dan metode pembelajaran konvensional terbukti. Jika dianalisis lebih jauh dengan menggunakan Uji Tuckey ternyata penggunaan metode pembelajaran pemecahan masalah memiliki efek yang lebih rendah bagi peningkatan kesadaran sejarah siswa SMA. Siswa yang memiliki kemampuan kemampuan berpikir kritis rendah memperoleh kesadaran sejarah yang lebih baik jika diberikan metode pembelajaran konvensional daripada jika diberikan metode pembelajaran pemecahan masalah.

\section{PENUTUP}

Hasil penelitian ini menunjukkan bahwa : (1) Pertama ; Tingkat kesadaran sejarah sejarah siswa SMA yang menggunakan pembelajaran dengan metode problem solving lebih tinggi dari siswa yang menggunakan metode pembelajaran konvensional. (2) Terdapat pengaruh interaksi antara metode pembelajaran dan kemampuan berpikir kritis terhadap kesadaran sejarah siswa SMA. (3) Tingkat kesadaran sejarah siswa SMA yang berpikir kritis tinggi dan menggunakan metode pembelajaran pemecahan masalah lebih tinggi dari siswa SMA yang berpikir kritis tinggi dan menggunakan metode pembelajaran konvensional. (4) Kesadaran sejarah siswa SMA yang berpikir kritis rendah dan menggunakan metode pemecahan masalah lebih rendah dari siswa SMA yang memiliki kemampuan berpikir kritis rendah dan menggunakan metode pembelajaran konvensional.

\section{DAFTAR PUSTAKA}

[1] Aman, Model Evaluasi Pembelajaran Sejarah, Yogyakarta: Ombak, 2011

[2] Arends, Richard I and Ann Kilcher, Teaching For Student Learning : Becoming An Accomplished Teacher. New York : Routledge, 2010

[ 3 ] Arikunto, Suharsimi. Prosedur Penelitian. Jakarta: Rineka CIpta, 2014

[4] Barrow, Howard S. And Wee Keng Neo Lynda. Principles and Practice of $a P B L$. Jurong: Pearson Education South Asia Pte.Ltd., 2007.

[ 5 ] Eggen, Paul and Don Kauchak. Educational Psychology. Ohio: Merryl Pearson, 2010

[6] Hasan, S. Hamid, Pendidikan Sejarah Indonesia : Isu dalam Ide dan Pembelajaran, Bandung : Rizqi Press, 2012

[ 7 ] Hasrudin, "Memaksimalkan kemampuan berpikir kritis melalui pendekatan kontekstual". Medan : Tabularasa, Vol 6 Nomor 1, Juni 2009 
[8] Putro, Herry Porda Nugroho. Model pembelajaran sejarah untuk meningkatkan kesadaran sejarah melalui pendekatan Iinkuiri. Banjarmasin: Paramita, 2012

[9] Reichenbach, Bruce R. Introduction to Critical Thinking. New York, Mc Graw Hill, 2001

[ 10 ] Thobroni, M. Belajar dan Pembelajaran : Teori dan Praktek, Yogyakarta: ArRuzz, 2015

[ 11 ] Urbina, Susana. Essential of Psychology, New Jersey: John Willey \& Sons, Inc, 2004 